\title{
GEOGRAFÍA LINGÜÍSTICA: A BRIEF INSIGHT INTO THE VARIETY OF THE SPANISH LANGUAGE ACROSS LATIN AMERICA
}

\section{Geografía lingüística: ieskats spāṇu valodas atšḳirībās Latīṇamerikā}

\author{
Margarita Feizaka \\ University of Latvia, Faculty of Geography and Earth Sciences \\ e-mail: margarita.feizaka@lu.lv
}

\begin{abstract}
While there are studies on differences between traditional Spanish and Latin American Spanish, they tend to either compare Castilian Spanish to one national variation in Latin America (e.g. Mexican Spanish) or assume that the whole region of Latin America is rather linguistically homogenous. This research aims to provide a brief insight into differences between variations of the Spanish language spoken in different countries in Latin America, comparing three local dialects: Mexican, Venezuelan and Chilean. Qualitative content analysis and the comparative method were applied to conduct the research. The findings suggest that there are differences in grammar usage and lexicon between different countries. While phenomena like anglicisms and changing prepositions were detected in all local dialects, Mexican Spanish stood out in terms of grammar, and Mexican and Venezuelan Spanish vocabulary showed specific local expressions.
\end{abstract}

Keywords: Spanish, Latin America, dialect, geolinguistics

DOI: $10.22364 / \mathrm{fg} .18 .6$

\section{Introduction}

While language geography, a branch of human geography, has been around for a while, most research into Spanish geolinguistics has had an emphasis on linguistic rather than geographical aspects (Yakubova et al. 2016; De la Mota et al. 2010; Llamazares et al. 2017). The presence of the Spanish language is an undeniable colonial legacy in hispanophone Central and South American countries. Brought to the continent in the $15^{\text {th }}$ century, it has developed and changed in accordance with local culture, history and traditions, resulting in differences from traditional Spanish. However, territorial differences within certain languages is a common phenomenon in our world - persons originating from anglophone Caribbean states use expressions that are no longer used in modern Great Britain, and the Bulgarian diaspora (Bessarabian Bulgarians) in Taraclia, a city in southern Moldova, still speak $19^{\text {th }}$ century Bulgarian - the same language their ancestors spoke when they migrated.

Generally speaking, existing studies on varieties of Spanish dialects can be categorised into two groups: the first group usually focuses on differences between traditional Spanish (Castilian) and Spanish in one particular country in Latin America. The second group, however, tends to assume that the whole region of Latin America is rather linguistically homogenous. The aim of this paper is to give a brief insight into 
the differences in the Spanish language between three Latin American states - Chile, Mexico and Venezuela - and to show that there are notable differences in grammar and vocabulary usage across the whole region.

\section{Theoretical background}

Previous studies on the variety of Spanish dialects have mainly described three linguistic properties: phonetics, grammar and lexicon.

The most notable phonetic phenomena in Latin American Spanish might be seseo, yeísmo and žeísmo - these increase the number of homophone words. The term seseo is used to describe the pronunciation of the letter $z$, which is usually pronounced as th [ð] in European Spanish. This sound, however, does not exist in Latin American Spanish at all - the $z$ is pronounced as $s$ [s] (Bradley et al. 2004). For example, rozado (worn) and rosado (pink) are homophones in Latin American Spanish, and so confusion might arise - is the dress worn or pink? The term yeismo describes the pronunciation of $l l$. While Spaniards, Bolivians and Paraguayans use the sound $[l j]$, most countries in hispanophone Central and Latin America use the sound $[j]$ - similar to the Latvian $j$. This, however, does not apply to Argentina and Uruguay, - where the sound [3], similar to the Latvian $\check{z}$ is used, which leads to another term - žeísmo. It is important to note that there are broad variations in phonetic specifics within regional dialects in Spanish - there are regions where speakers do not pronounce the letter $r$ if it is the last letter of the word, Mexican Spanish speakers and older speakers of European Spanish tend to pronounce $x$ as $[h]$ instead of $[k s]$ or $[s]$, aspiration of $s$ is common in Guatemala, Peru and Colombian Andes (Hualde 2005), velarisation of $n$ is common in Yucatan, Mexico; and Tucuman, Argentina, etc. ... While phonetics might be the most obvious difference in verbal communication, analysis of written language is rather complicated.

The differences in grammatical constructions are less diverse than those in phonetics. There are differences in usage of grammatical tenses - it is argued that traditional Spanish speakers prefer the present perfect and Latin American Spanish speakers prefer the past simple (Gutin 2012). Latin American Spanish dialects tend to have different personal pronouns which also affects the conjugation of the verbs that follow. While the second person singular pronoun in traditional Spanish and most of Latin America is tú, this pronoun does not exist in Argentina and Uruguay, or in some parts of Chile, Guatemala and Bolivia (Figure 1). Instead, these regions use the pronoun vos, which does not exist in traditional Spanish, but is sometimes used as the informal short form of the second person plural pronoun vosotros. Hence, the verb following vos is conjugated in the second person plural. You are - traditional tú eres in some Latin American dialects vos sos (Gutin 2012).

In Castilian Spanish, the second person plural pronoun is vosotros, and the second person singular formal pronoun is usted (the plural form is ustedes, after which the following verb is conjugated in the third person). Latin American Spanish, however, does not feature the pronoun vosotros at all-ustedes is used as the second 
person plural pronoun and the plural for usted as well. In this case, even if ustedes is used as second person plural pronoun, the following verb is conjugated in the third person (Shaw et al. 2005).

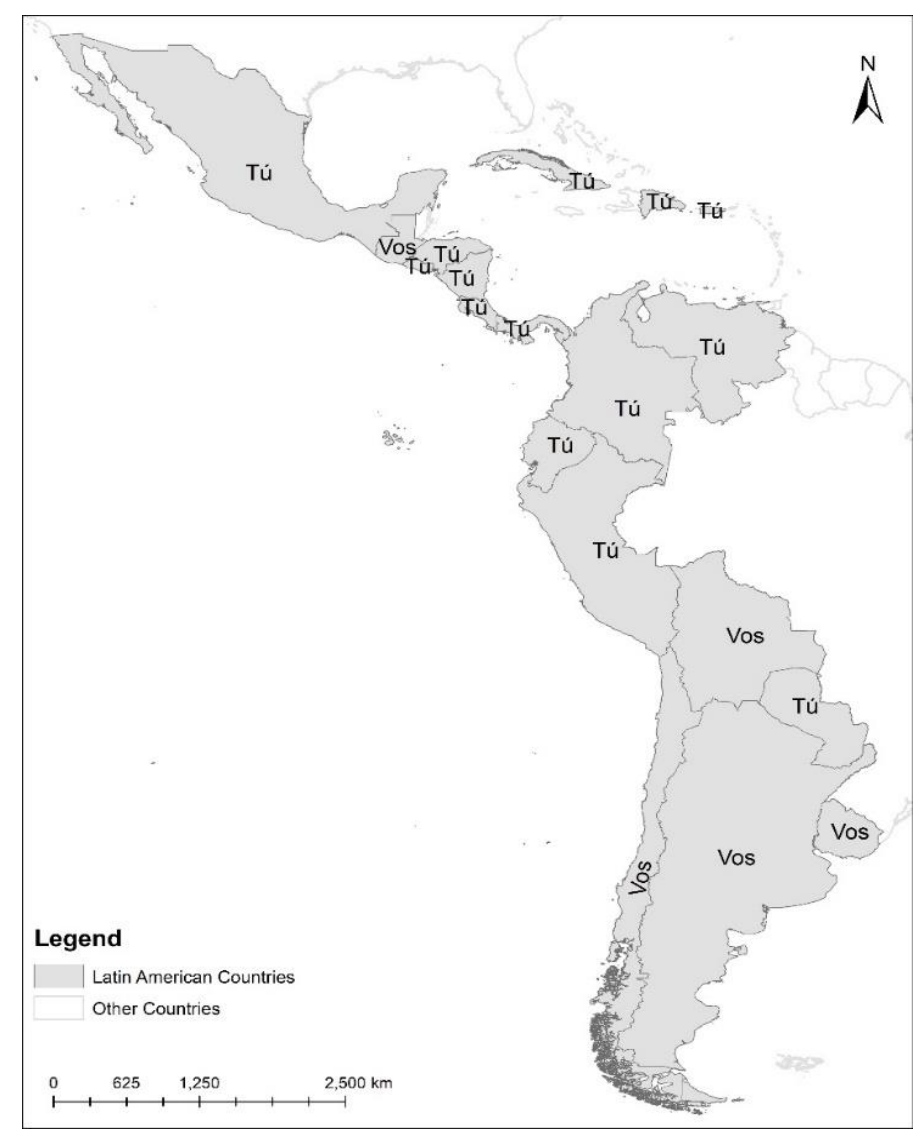

Figure 1. Usage of second person singular pronoun across Latin America (author's figure based on Gutin 2012 and ESRI spatial data)

Finally, the varieties of lexicon in Latin American Spanish suggest that regional differences are affected by local culture, ethnicities and traditions. There is a general notion that speakers of Latin American Spanish tend to use more anglicisms, compared to Castilian Spanish (Shaw et al. 2005). There are also many cases of homonyms across Latin America, for example - cuadra, which means "stable" in Spain and "neighbourhood" in Colombia; or, guagua, which means "infant" in the Andes and "bus" in Cuba. Mexican Spanish is heavily influenced by native Indian languages, such as Nahuatl and Mayan (Hualde 2005).

\section{Methodology}

This research took place in Germany. The research involved three participants, each representing a country in Latin America: Mexico, Chile and Venezuela. The participants share similar backgrounds, they are well-educated young adults and are from the upper socio-economic class. The participants were aware that they were 
participating in a research project. The participants were asked to translate a text from German to Spanish (each participant's knowledge of German is C1 level, according to the Common European Framework of Reference for Languages). The original text describes a casual situation and does not contain specific terminology or complicated structures.

The translation was used to conduct qualitative content analysis. The comparative method was also used to carry out the analysis. The analysis had an emphasis on grammatical structures and lexicon; the grammatical structures used by the participants were compared to traditional Spanish and to structures used by other participants. Specific lexical usages were compared to both traditional Spanish and the vocabulary used by other participants. It is important to note that linguistic qualitative content analysis takes the general context into account, such as local cultural, political and historical influences.

\section{Results}

The findings suggest that there are differences in grammar and lexicon between the three Latin American Spanish speaking countries and Castilian Spanish (Table 1). While the three countries share some similarities, such as anglicisms and changing prepositions, local specifics can be distinguished.

Table 1 . Summary of the regional differences

\begin{tabular}{|c|c|c|c|}
\hline & Mexico & Chile & Venezuela \\
\hline Grammar & $\begin{array}{c}\text { Adding direct object } \\
\text { pronouns; } \\
\text { Skipping auxiliary verbs; } \\
\text { Dequeísmo; } \\
\text { Adding demonstrative } \\
\text { pronouns; } \\
\text { Changing prepositions; } \\
\text { Diminutives; } \\
\text { Sólo; } \\
\text { Missing contraction } a l\end{array}$ & $\begin{array}{l}\text { Changing prepositions; } \\
\text { Missing contraction al }\end{array}$ & Changing prepositions \\
\hline Lexicon & $\begin{array}{l}\text { Anglicisms; } \\
\text { Toparse; } \\
\text { Bien feliz; } \\
\text { Juntarse; } \\
\text { Chingo; } \\
\text { Ir a tomar }\end{array}$ & $\begin{array}{l}\text { Anglicisms; } \\
\text { Juntarse }\end{array}$ & $\begin{array}{c}\text { Anglicisms; } \\
\text { Epa; } \\
\text { Chévere; } \\
\text { Rumbear }\end{array}$ \\
\hline
\end{tabular}

Table 1 shows that the most grammatical and vocabulary differences were found in the Mexican Spanish text. The author of the Mexican Spanish text added direct object pronouns, such as $l o$, when they were not a grammatical necessity and skipped the auxiliary verb estar several times. A common phenomenon in Latin American Spanish - dequeísmo - was detected. Subordinate clauses in Spanish can be 
introduced by the complementizers que or de que. However, in verbal communication, de que is often used where que is more appropriate, which is considered incorrect and informal (Martinez-Sequeira 2002; Rabanales 2005). Additionally, demonstrative pronouns were often overused - the demonstrative pronoun eso was often followed by $l o$, which is not required. The Mexican Spanish text also showed a significant number of diminutives. One further point is that the word sólo was spelled with an $o$, although in 2010, it was decided to that is should be spelled without an accent (Cinco Dias 2010). Some of the differences in vocabulary usage detected are known to be typical of Mexican Spanish speakers. While Castilian Spanish speakers use the verb encontrarse to describe an intended meeting, and toparse is used to describe an unintended meeting, in Mexican Spanish toparse carries the meaning of an intended meeting. Also, the phrase bien feliz shows another phenomenon of Mexican Spanish, where the word muy is often replaced by the word bien. Chingo and ir a tomar are phrases that are used only in Mexico. While the word chingo can be interpreted in many ways, it means great in this context.

In both the Mexican and the Chilean texts, the contraction al was missing. In Castilian Spanish, the phrase contestar al teléfono requires al, the contraction of the preposition $a$ and the article $e l$. However, in Latin America, it is common to simply use $e l$ instead of $a l$, which is considered incorrect in Castilian. Additionally, Chilean and Mexican texts shared a common feature of vocabulary - juntarse, a reflexive verb that is widely used in Latin America to describe meeting someone. The citations below demonstrate how diverse the translations can be:

"" "Hey!" dijo Marisol cuando se ha topado con Juan. "¿Cómo te lo va?" Juan estaba bien feliz de que el se la haya encontrado y el le dijo: "iHey, Marisol! A mi me va bien, gracias y ¿A ti? ¿Que haciendo? Hace poquito tiempo de que Marisol se compró un carro nuevo y estaba claro de que eso no lo pudo evitar, por eso ella le contó todo el rollo." (Mexican translation)

"“"Hola!" dijo Marisol al encontrarse con Juan. ¿¿Cómo te va?" Juan estaba muy alegre de encontrársela y dijo: ";Hola, Marisol! Me va muy bien, gracias, ¿y a ti? ¿Qué haces?" Marisol se habia comprado recientemente un auto y eso no pudo evitarlo, por eso se lo contó a Juan." (Chilean translation)

“,Epa!!!” Dijo Marisol cuando se encontró a Juan "Cómo estás?" Juan estaba muy feliz, porque se la había encontrado y dijo: "Hey Marisol! Chévere, gracias y a ti? Qué haces?". Marisol se habia comprado un carro y no podia evitar no contárselo a Juan." (Venezuelan translation)

In terms of grammar, the Venezuelan text was the closest to Castilian Spanish, however, there were differences in lexicon that are characteristic of Venezuela. Firstly, the greeting epa is used only in Venezuela, Bolivia and El Salvador. Secondly, the term chévere, meaning great, is used only in hispanophone countries located in the Caribbean basin. The same applies to rumbear, which is a verb used in the Venezuelan text to describe partying. The etymology of the noun rumba dates to $19^{\text {th }}$ century Cuba, where the term was initially used as a synonym for a party. Considering the geographic location of Venezuela, its history and the fact that Venezuela shares major 
cultural similarities with the hispanophone Caribbean islands (Mato 2003), the usage of rumbear is not surprising. It would, however, be a surprise to find this term in Chilean and Mexican texts, since rumba is not a part of their culture.

Additionally, cultural differences were detected when comparing the whole texts. The Chilean translation appeared to be the most formal, correct and accurate one. The Mexican and Venezuelan texts, however, carried a wholly different level of temperament in them, which can be literally felt when reading them. This is another evidence of the differences in mentality between different Latin American countries, since Chileans are known to be the most reserved and secretive Latin Americans.

Anglicisms, such as jeans, carro (car), hey, auto, etc. were widely used in all the analysed texts. The influence of the English language on Latin American Spanish is stronger than on Castilian Spanish (Shaw \& Dennison 2005; Academia Chilena de la Lengua 2010), mainly due to geographic location and history. The phenomenon of changing prepositions was also found in all the texts. All the participants translated the phrase tonight as en la tarde, however, the correct phrase in Castilian Spanish would be por la tarde- all the participants replaced the preposition por with en. In the text translated by the Venezuelan participant, the verb encontrarse was followed by the preposition $a$, whereas Castilian Spanish requires the preposition con.

\section{Conclusion}

While there are studies on differences between traditional Spanish and Latin American Spanish, they tend to either compare Castilian Spanish to one national variation in Latin America (e.g. Mexican Spanish) or to assume that the whole region of Latin America is rather linguistically homogenous. This research successfully proved that there are geographical differences within the Spanish language, and that Latin American Spanish has local variations in different countries, and therefore, the region should not be considered linguistically homogenous.

The findings suggest that anglicisms and changing prepositions are typical of all three countries studied. Mexican Spanish differs from Castilian, Chilean and Venezuelan grammatically, featuring such phenomena as diminutives, dequeísmo, excessive usage of direct object pronouns and demonstrative pronouns, while Venezuelan and Chilean Spanish do not differ significantly in their grammar from traditional Spanish. Mexican Spanish and Venezuelan Spanish presents a unique vocabulary. While there are terms that are common only in Mexico, Venezuelan Spanish is heavily influenced by the Caribbean Spanish speaking countries and their cultures, therefore, some terms are shared with hispanophone Caribbean countries, such as Cuba.

Since there are a lack of studies in geolinguistics that focus on Spanish, it is advisable to conduct further research on this topic. This research was based on written language; therefore, phonetic aspects were not analysed. However, research on phonetic variations of Spanish across Latin America would contribute to the debate on how linguistically heterogenous the region is. It is important to note that the aim of 
this paper is to provide a brief insight in national varieties of the Spanish language in Latin America. An in-depth analysis would reveal a more detailed picture. An empirical study with a large amount of data would allow quantitative content analysis to be conducted and statistically validated results to be presented.

\section{Acknowledgement}

This study was supported by National Research Program Project No. VPPIZM2018/1-0015.

\section{Kopsavilkums}

Lai gan pastāv pētījumi, kas salīdzina tradicionālo spāṇu valodu ar Latīṇamerikas spāṇu valodu, pārsvarā uzsvars tiek likts uz salīdzinājumu starp tradicionālo spāṇu valodu un vienas Latīṇamerikas valsts vietējo variāciju (piemēram, meksikāṇu spāņu valodu), vai arī tiek pieņemts, ka Latīṇamerika ir lingvistiski homogēns reǵions. Šì pētījuma mērkis ir sniegt ieskatu Latīṇamerikas valstu spāṇu valodas nacionālajās variācijās, salīdzinot trīs vietējos dialektus: meksikāṇu, venecuēliešu un čìliešu. Pētījums tika veikts izmantojot kvalitatīvo kontentanalīzi un salīdzinošo metodi. Rezultāti parāda, ka pastāv nacionālas atšķirības leksikas, vārdformu un sintaktisko konstrukciju lietojumā. Tādi fenomeni kā anglicismi un prievārdu main̄̄šana tika atklāti visos pētītajos dialektos, savukārt Meksikas spāņu valoda izcēlās gramatikas lietojumā. Meksikas un Venecuēlas piemērs norāda uz specifisku izteicienu lietojumu, kas ir raksturīgi tikai šīm valstīm.

\section{References}

Academia Chilena de la Lengua. (2010). Diccionario de uso del español de Chile (DUECh). MN.

Bradley P.T., Mackenzie I.E. (2004). Spanish: an essential grammar. New York: Routledge.

Cinco Dias (2010). La RAE publica las nuevas normas de ortografía. https://cincodias.elpais.com/cincodias/2010/11/05/sentidos/1289093002_850215.html (29.02.2020).

De la Mota, C., Butragueño, P.M., Prieto, P. (2010). Mexican Spanish intonation. Transcription of intonation of the Spanish language, 319-350.

Gutin, J. (2012). The Everything Spanish Book: All the rules you need to master Espanol. Avon: Adams Media.

Hualde, J.I. (2005). The Sounds of Spanish. Cambridge: Cambridge University Press.

Llamazares, I., Marcos-Marne, H., Martín-Vallejo, J. (2017). Peripheral identities in contemporary Spain. Ethnicities, 17 (6), 844-866.

Martines Sequeira, A.T. (2002) Dequeismo in the Spanish of Costa Rica: a semantic-pragmatic analysis. Oakland: University of California.

Mato, D. (2003). Crítica de la modernidad, globalización y construcción de identidades: (debate de modernidad/postmodernidad, globalización y construcción de identidades y otras representaciones sociales: consideraciones teóricas y estudios sobre Venezuela, América latina y el Caribe), 42, CDCH UCV.

Pino Silva, J., Antonini Boscan, M. (2017). Pérdida/adquisición de dialectos del español. Lenguas Modernas, 20, 105-112.

Rabanales, A. (2005). Queísmo y dequeísmo en el español de Chile. Onomázein: Revista de lingüistica, filología y traducción de la Pontificia Universidad Católica de Chile, 12, 23-53.

Shaw, L., Dennison, S. (2005). Pop Culture Latin America! Media, Arts and Lifestyle. Santa Barbara: ABC-CLIO. 